\title{
BUILDING SOCIAL AND EMOTIONAL SKILLS IN STUDENTS IN THE CONTEXT OF DISTANCE LEARNING
}

\author{
Liliia Hrynevych ${ }^{1}$ \& Nataliia Morze $^{2}$ \\ Borys Grinchenko Kyiv University, 18/2 Bulvarno-Kudriavska Str., Kyiv, Ukraine \\ ${ }^{1} 1$. hrynevych@kubg.edu.ua, ORCID 0000-0002-5818-8259 \\ 2n.morze@kubg.edu.ua, ORCID 0000-0003-3477-9254
}

\begin{abstract}
The paper discusses the essence of social and emotional learning, highlighting the need to develop students' soft skills in the ever-shifting world, as well as during the time of pandemic. Social and Emotional Learning is a vehicle for shaping soft skills as it focuses on the development of such capacities as self-awareness; social awareness; self-management; relationship skills; and responsible decision making. The paper presents some findings from the 2021 representative survey of teachers and school principals across Ukraine (involving 3,237 teaching staff and 420 school principals) that was aimed at determining the level of educators' acceptance and readiness to implement Social and Emotional Learning as part of the New Ukrainian School Reform. It takes stock of teachers' capacity in building the skills to proceed with the implementation of Social and Emotional Learning, in particular regarding in-service training, knowledge of methodologies for soft skills development, access to electronic resources, methodological and training materials, individual education programmes on Social and Emotional Learning, and allocation of school time for their implementation. The paper underlines the increasing role of building social and emotional skills in distance-learning settings and describes various ways in which teachers can employ digital tools to facilitate effective transition to electronic learning while taking into consideration students' learning styles and the need to build social and emotional skills.
\end{abstract}

Keywords: social and emotional learning (SEL), soft skills, social and emotional skills (SES), digital tools, distance learning.

\section{INTRODUCTION}

The concurrent processes of globalization and digitalization have generally broadened horizons, expanding possibilities to access information in the world. At the 
same time, these very processes have contributed to greater confusion, unpredictability, and ambiguity in the modern world.

In the era of major global transformations, contemporary educational systems cannot simply strive to transfer academic knowledge to students, since children need to acquire a balanced set of cognitive, social and emotional skills for their successful self-fulfilment in life. Schools are to prepare children for present and future challenges, boost their confidence and self-efficacy.

How can we achieve this goal? By building and developing in children the social and emotional skills that are relevant for the $21^{\text {st }}$ century and that have proven instrumental for coping with life changes in today's highly globalized and dynamic world. Social and emotional skills are also defined through such concepts as 'soft skills', 'transversal skills', interpersonal skills', 'skills of the 21st century', etc.

Chernyshenko, Kankaraš and Drasgow point out that the development of social and emotional skills is important not only for individuals, but also for communities and societies at large. The abilities of citizens to flexibly adapt to changes in the world, to respect their own dignity and the dignity of others, to maintain healthy relationships in their communities, to show ingenuity, responsible and ethical decision-making all these and other important soft skills have become the essential attributes of a successful country (Chernyshenko, Kankaraš, \& Drasgow, 2018).

Authors of the "Handbook of Social and Emotional Learning: Research and Practice" point out that numerous definitions of social skills are exist but according to the Greshman (2002) they describe social and emotional skills as, "a set of behaviours that facilitates the initiation and maintenance of positive social relationships, contributes to peer acceptance, allows individuals to cope with and adapt to the demands of the social environment, and results in satisfactory school adjustment" (Durlak, Domitrovich, Weissberg, \& Gullotta, 2017: 301).

According to the Greshman and Elliott (1984, 1990, 2008), social skills are defined as "socially acceptable, learned behaviors that enable an individual to interact effectively with others and to avoid or escape unacceptable behaviors that result in negative social interactions with others" (Durlak, Domitrovich, Weissberg, \& Gullotta, 2017: 302).

Social and Emotional Learning (SEL) is a tool for building and developing social and emotional skills. SEL is a foundation for the enhanced academic performance of students and, most importantly, for their successful and happy life.

The authors of the work "Promoting social and emotional learning: Guidelines for educators" understand Social and Emotional Learning as, "the process of acquiring core competences to recognize and manage emotions, set and achieve positive goals, appreciate the perspectives of others, establish and maintain positive relationships, make responsible decisions, and handle interpersonal situations constructively" (Elias, Zins, Weissberg et al., 1997: 5).

The Collaborative for Academic, Social, and Emotional Learning (CASEL) identifies five key competences developed through SEL:

- Self-awareness - abilities to identify and recognize one's own emotions, their influence on behaviours and actions, to recognize one's strengths and 
limitations, as well as self-esteem and self-efficacy, optimism and confidence in oneself;

- Social awareness - abilities to feel compassion for others, empathy, respect for oneself and others;

- Self-management - abilities to effectively manage one's behaviour, thoughts, and emotions, to focus, to solve problems, to relax, as well as positive thinking and the ability to listen;

- Relationship skills - abilities to establish and maintain healthy relationships in society, to ask for and provide help, to communicate and collaborate;

- Responsible decision-making - abilities to make constructive, responsible, and ethical decisions that promote personal and community well-being, to effectively manage goals and resources (www.casel.org).

Well-developed social and emotional skills are important drivers of academic performance in typical learning settings. This has been confirmed by results of the international study conducted by the Organization for Economic Co-operation and Development (OECD).

Beyond Academic Learning has been the first international comparative survey to examine and evaluate the conditions and factors contributing or inhibiting to the development of social and emotional skills in children aged 10 and 15.

The survey found that the development of social and emotional skills in children, unlike academic knowledge, does not follow a steady growing pattern (OECD, 2021). The findings revealed that all 15-year-olds, regardless of gender and social background, reported lower social and emotional skills than 10-year-olds. Assessments given by parents and teachers also confirmed a decline of social and emotional skills as children grow. Furthermore, it was established that levels of creativity and natural curiosity were also lower among 15 -year-olds as compared to 10 -year-olds. Although the decline in soft skills could be partially attributed to individual development factors, it is indisputable that the educational system plays a significant role in stamping out intellectual curiosity, imagination, and creativity as children grow.

An important finding of the Beyond Academic Learning survey shows that social and emotional skills are indeed strongly related to school performance, notably in reading, mathematics, and arts. There is a general misconception that social and emotional learning squeezes out academic learning, whereas in reality, the former enhances the latter, thus strengthening students' learning outcomes.

It is a child's natural curiosity towards diverse topics that underlies the powerful intrinsic motivation for learning and the acquisition of new academic knowledge. According to the survey findings, the key social and emotional skills contributing to better academic performance in mathematics among 10- and 15-year-olds are persistence, trust, and curiosity (OECD, 2021).

Today, all advanced educational systems around the world place strong emphasis on the introduction and development of soft skills, with progressive educators, non-governmental, parents' and employers' organizations joining efforts towards this goal. Thus, in 2018 the EU Council Recommendation introduced the Personal, Social and Learning to Learn Competence, or LifeComp, to the set of key competencies for lifelong learning. The LifeComp Framework regards a set of competences important 
for any person in the $21^{\text {st }}$ century for a happy and successful life. The Forward section identifies three groups of cross-cutting skills, each comprising three competencies:

1. Personal Competence:

- P1 Self-regulation;

- P2 Flexibility;

- P3 Wellbeing.

2. Social Key Competence:

- S1 Empathy;

- S2 Communication;

- S3 Collaboration.

3. Learning to Learn Key Competence:

- L1 Growth mindset;

- L2 Critical thinking;

- L3 Managing learning.

(Sala, Punie, Garkov, \& Cabrera, 2020).

In 2017, Ukraine launched the New Ukrainian School Reform that specifically emphasized a shift from 'knowledge-centred' to 'competence-centred' schooling, meaning that teaching should focus not only on academic knowledge but also on social and emotional learning and ethics.

A cornerstone of the New Ukrainian School Reform is education based on values and the transversal shaping of values in the educational process, development of attitudes and soft skills. Thus, the key competencies of the New Ukrainian School include:

- Fluent proficiency in the official language of the state

- Ability to communicate in a native language (if different from the official language) and foreign languages

- Mathematical competence

- Competence in science and technology

- Information and communication competence

- Environmental competence

- Innovation

- Lifelong learning

- Civic and social competences

- Cultural competence

- Entrepreneurship and financial literacy

The Ukrainian Law on Education (2017) lists the following skills common for all key competencies:

reading comprehension,

- ability to express one's thoughts orally and in writing,

- critical and systemic thinking,

- ability to logically argue for one's position,

- ability to cope with one's emotions in a constructive way,

- ability to assess risk,

- ability to make decisions,

- ability to solve problems,

- ability to collaborate, 
- creativity,

- initiative.

To assess the level of acceptance and preparedness of the educational community as to the introduction of social and emotional learning within the New Ukrainian School Reform, a nationwide survey was carried out from January through July 2021 among teachers and school principals, with findings presented in the analytical report, the "Feasibility Study on Opportunities for SEL within New Ukrainian School Reform" (Hrynevych, Drozhzhyna, Hloba et al. 2021).

The survey included a representative sample of 3,657 respondents $(3,237$ members of teaching staff and 420 school principals), covering:

- a core group of schools,

- 20 schools with close proximity to the contact line, and

- 26 schools participating in the nationwide experiment "Organizational and pedagogical conditions for building soft skills in students through teaching social and emotional skills and ethics" and therefore, having experience with the implementation of one of the advanced areas of SEL.

The survey has found that SEL is generally perceived in a positive way $(61.7 \%$ of teachers and $69.2 \%$ of school principals recognized SEL as 'definitely positive'), especially in schools that already had some experience with SEL (Figure 1).

Teachers who practice SEL should possess certain skills, which is recognized by $85.1 \%$ of surveyed teachers and $90.2 \%$ surveyed school principals. $78.5 \%$ of teachers believe that social and socio-ethical competencies are needed by all teaching staff in schools.

What would be your general assessment of SEL as a field of education?

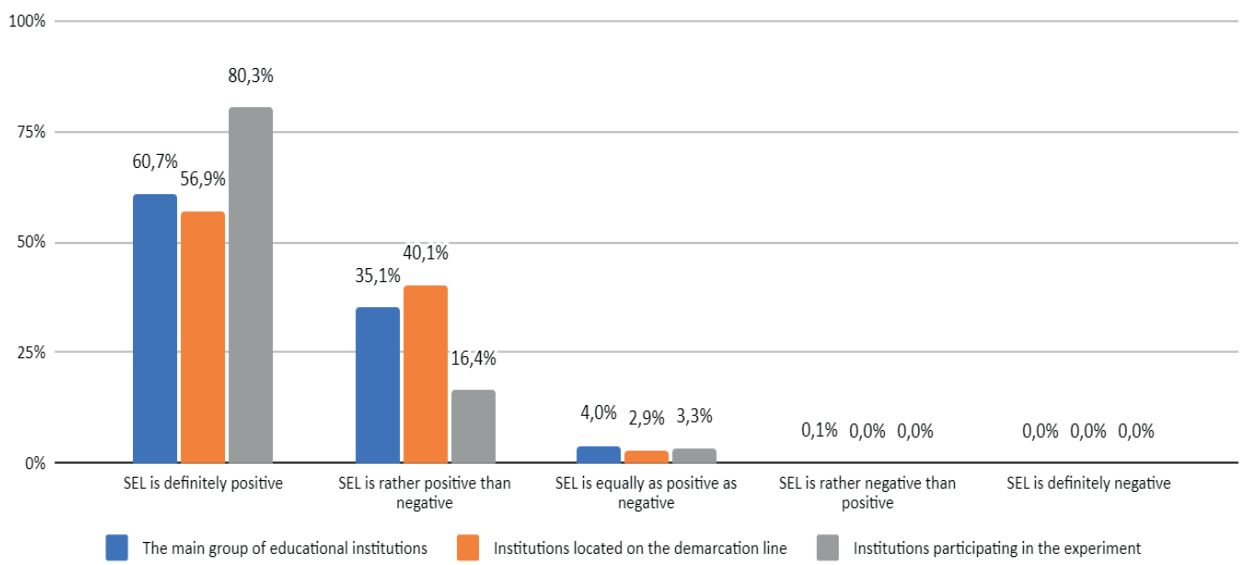

F ig u re 1. Distribution of respondents' answers to the question "What would be your general assessment of SEL as a field of education?"

According to teachers participating in the survey, the least developed social and emotional skills in students are:

- ability to perform multi-step assignments (only $20.5 \%$ of respondents stated that this ability was developed in at least half of students in a school), 
- ability to understand the interdependent nature of our world $(20.6 \%)$, and

- emotional empathy (22.5\%).

Compassion was reported to be the most-developed skill (60.3\%), despite the fact that compassion and emotional empathy are inter-connected, and the former is impossible without the latter (Figure 2).

Which of the following social and emotional skills, in your opinion, are developed in at least half of students in your school?

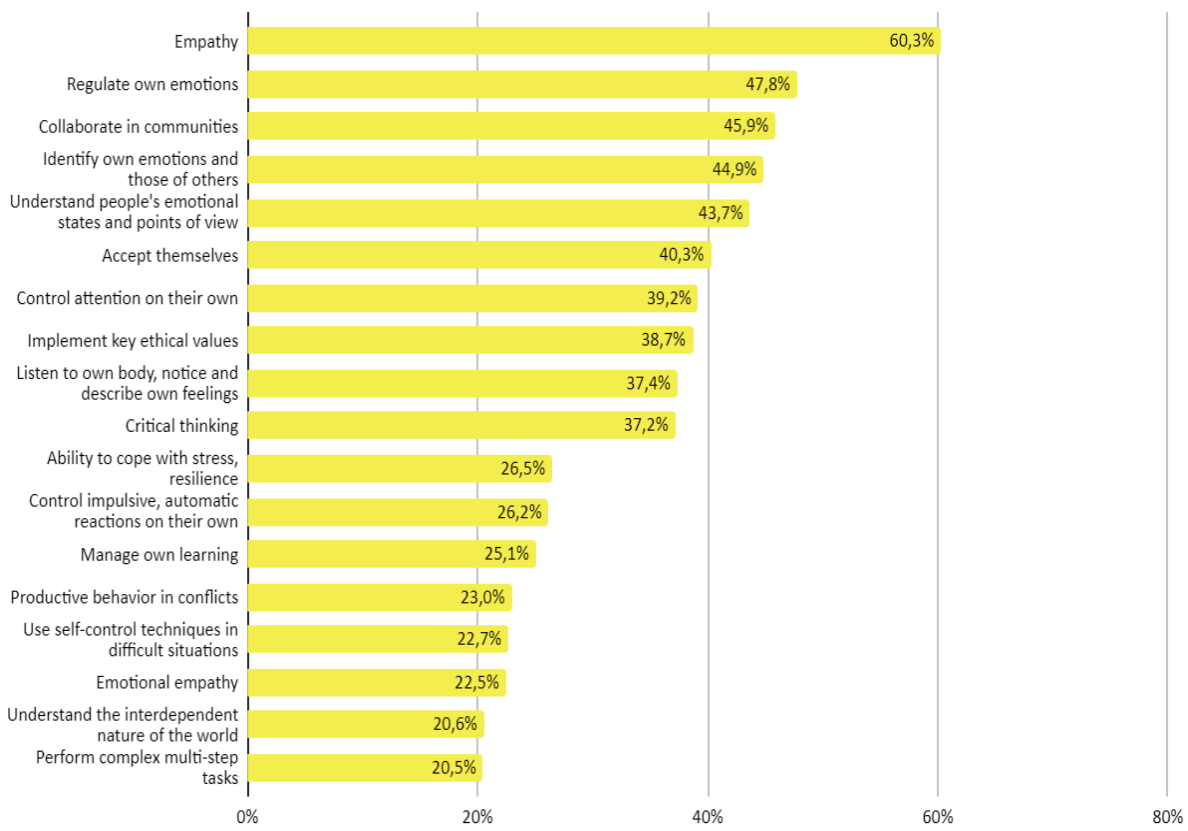

F i g u r e 2. Distribution of respondents' answers to the question "Which of the following social and emotional skills, in your opinion, are developed in at least half of students in your school?"

When asked, "To what extent are the following social and emotional skills developed in you personally?", in both groups the 'outsiders' appeared to be:

- the ability to use self-regulation techniques in challenging situations $(33.2 \%$ of teachers and $34.6 \%$ of school principals), and

- the ability to cope with stress, resilience $35 \%$ of teachers and $38.9 \%$ of school principals).

Therefore, the development of soft skills is needed not only by students, but also by teachers themselves. $59.6 \%$ of respondents among teachers stated they were definitely willing to engage in in-service training on SEL (with an additional 31.9\% who chose the "more likely than not" response). However, they also pointed out a lack of opportunities: $55 \%$ of respondents among teachers reported that they had not participated during the last 12 months in any in-service training programme that would at least include some SEL topics. 
At the same time, the findings suggest that school principals are prepared to implement SEL in a systematic way: $44 \%$ of school principals would definitely want it, and a further $44.3 \%$ chose the "more likely than not" response (Figure 3 ).

Would you be willing to implement SEL in a systemic way in the school you lead?

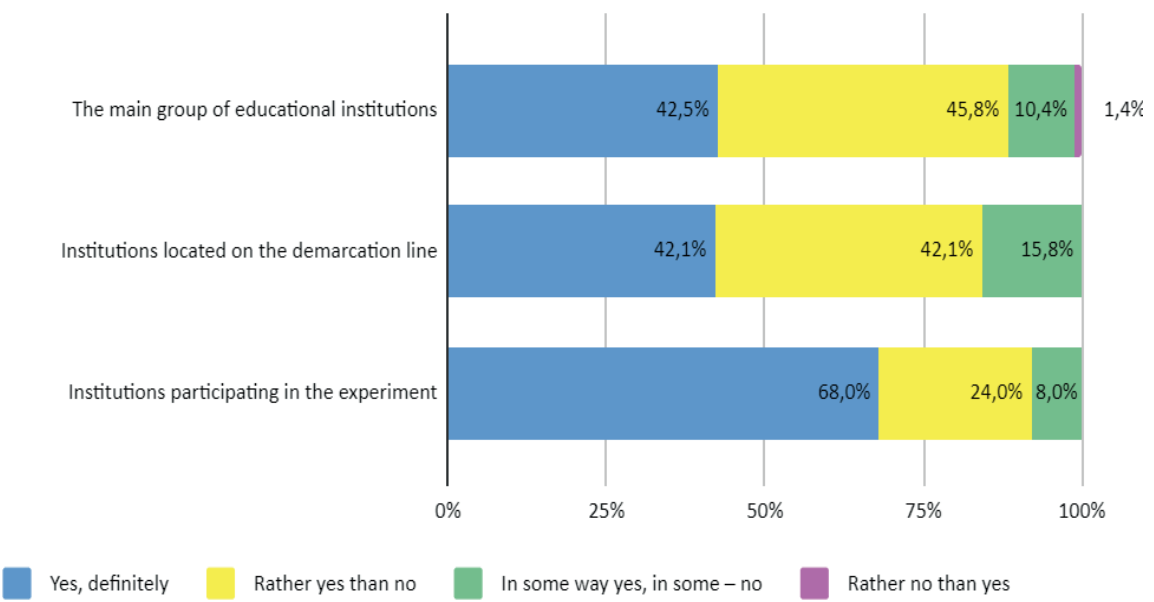

F ig u r e 3. Distribution of respondents' answers to the question "Would you be willing to implement SEL in a systematic way in the school you lead?"

When asked, "What kind of support do you personally need to implement SEL in the most effective way?" teachers most frequently selected the following answer options:

- creating a basic online course with supportive information and methodological materials $(66.7 \%)$;

- availability of information and methodological materials on how to communicate this topic to parents $(43.2 \%)$;

- introducing a model SEL curriculum (29.9\%);

- participation in professional networks of colleagues who implement SEL (26.4\%);

- systemic public policy backed up by the Ministry of Education and Science (26.2\%);

- support from parents $(22.9 \%)$;

- including SEL in the variable part of the curriculum (22.8\%);

- presence of SEL elements in model subject-specific programmes (22.3\%). (Hrynevych et al., 2021: 228-229).

Thus, both teachers and school principals recognize the importance of developing social and emotional skills in the educational process and are prepared to implement SEL in their schools. However, they lack the respective capacity building, knowledge of methodologies and necessary methodological and learning materials. 


\section{CHALLENGES RELATING TO DISTANCE LEARNING AND SEL}

In situations of crisis, the role of soft skills tends to become even more prominent, compared to normal, mundane settings. The OECD researchers highlight that lack of proper socialization with peers and teachers due to the forced restrictions during the COVID-19 pandemic and missed school time affect not only children's academic performance but also their mental state and social skills (an ability to build and maintain positive, healthy relationships in the community after the crisis subsides) (OECD, 2021). The authors of the Beyond Academic Learning survey point out that the pandemicinduced transition to distance learning has underscored the importance for children to develop such skills and abilities as an intrinsic motivation to learn, time management, and emotional self-regulation. The development of strong social and emotional skills is central for students to remain focused and motivated in challenging learning environments and various situations of crisis.

The COVID-19 pandemic has affected multiple areas of our life - from economy to education. The pandemic-related crisis has highlighted the importance that should be attached not only to building cognitive skills but also social and emotional skills as well as ethical skills, to be able to effectively respond to the challenges of the modern world. We cannot insulate and shield children from all difficulties and challenges in life, and there will always be things beyond our control. However, we are to use such difficulties as a teachable moment and be able to adapt to the requirements of the time (OECD, 2021).

The pandemic has also underscored the importance of transformations in the school system to enable the fostering of emotional, social, and ethical skills in children. Teachers should be presented with opportunities to learn and use SEL tools as a valuable component of the education process in its own right, so that each and every child in Ukraine could acquire the soft skills necessary in the $21^{\text {st }}$ century as part of mandatory schooling.

SEL implementation in the current curricula may only be possible through the respective capacity building of teachers and equipping them with methodologies and support materials suited for students of different ages.

\section{SEL DEVELOPMENT IN THE CONTEXT OF DISTANCE LEARNING}

Faced with digital transformations in education and reliance on distance and mixed learning formats, teachers should have sufficient levels of information and communication competence to be able to manage the development of social and emotional skills in children using digital technologies, especially considering the fact that the modern-day Gen Alfa students are firmly immersed in and embrace technology.

According to Professor Diana Laurillard, teachers should know and be able to make the transition from traditional to innovative pedagogical methods in the organization of classroom learning using digital technologies (Hrynevych, Iliich, Lyniov et al., 2020) (Table 2). 
Table 2. Transition from traditional to innovative pedagogical methods in the organization of classroom learning using digital technologies

\begin{tabular}{|c|c|c|}
\hline Learning style & Description of student activity & Use of digital tools \\
\hline Studying & $\begin{array}{l}\text { Students learn when they listen to } \\
\text { a teacher or podcast, read books } \\
\text { or websites, watch demonstration } \\
\text { video-clips. }\end{array}$ & $\begin{array}{l}\text { Reading from multimedia, } \\
\text { websites, digital documents and } \\
\text { resources, listening to podcasts, } \\
\text { web-broadcasts, watching anima- } \\
\text { tion films, video-clips. }\end{array}$ \\
\hline Collaboration & $\begin{array}{l}\text { Includes discussion, practice, } \\
\text { and production (presentation of a } \\
\text { product). Based on research and } \\
\text { acquired knowledge. Participation } \\
\text { in fostering one's knowledge. }\end{array}$ & $\begin{array}{l}\text { Small group projects using online } \\
\text { tools, forums, chats, etc. to dis- } \\
\text { cuss other participants' results, } \\
\text { creation of joint digital products. }\end{array}$ \\
\hline Discussion & $\begin{array}{l}\text { Learning through discussion re- } \\
\text { quires students to formulate their } \\
\text { ideas and questions, solicit ideas } \\
\text { from others, answer questions } \\
\text { from a teacher and other students. }\end{array}$ & $\begin{array}{l}\text { Online learning materials/ text- } \\
\text { books, discussion via email and } \\
\text { messengers, discussion groups, } \\
\text { discussion forums, whiteboards, } \\
\text { video conferencing tools (syn- } \\
\text { chronous and asynchronous). }\end{array}$ \\
\hline Exploration & $\begin{array}{l}\text { Learning through exploration } \\
\text { allows students to examine, } \\
\text { compare and critique texts, docu- } \\
\text { ments and resources reflecting } \\
\text { education concepts and ideas. }\end{array}$ & $\begin{array}{l}\text { Using online tips (information) } \\
\text { and recommendations, analysing } \\
\text { ideas and information from mul- } \\
\text { tiple digital sources, using digital } \\
\text { tools to collect and analyse data, } \\
\text { comparing digital texts, using } \\
\text { digital tools to look for and evalu- } \\
\text { ate information and ideas. }\end{array}$ \\
\hline $\begin{array}{l}\text { Task } \\
\text { performance }\end{array}$ & $\begin{array}{l}\text { Learning through practice allows } \\
\text { students to tailor their actions } \\
\text { according to their goal / task and } \\
\text { use feedback for improvement. } \\
\text { Feedback can come from self-re- } \\
\text { flection, from peers, teachers, or } \\
\text { activity itself if it shows students } \\
\text { how to improve the result accord- } \\
\text { ing to their goal. }\end{array}$ & $\begin{array}{l}\text { Using simulation models, micro- } \\
\text { education, online simulators, } \\
\text { virtual labs and tours, online role } \\
\text { play. }\end{array}$ \\
\hline $\begin{array}{l}\text { Production } \\
\text { (product } \\
\text { creation) }\end{array}$ & $\begin{array}{l}\text { Learning through production } \\
\text { (product creation) is a way for a } \\
\text { teacher to encourage students to } \\
\text { put together all they have learnt } \\
\text { through conceptual understand- } \\
\text { ing and understanding of how it } \\
\text { can be applied in practice. }\end{array}$ & $\begin{array}{l}\text { Creating and storing digital } \\
\text { documents, presenting projects, } \\
\text { shows, artefacts, animation films, } \\
\text { models, resources, slideshows, } \\
\text { photos, videos, blogs, electronic } \\
\text { portfolios. }\end{array}$ \\
\hline
\end{tabular}


Digital tools and services that help teachers manage learning objectives and assignments while organizing distance learning include (Dziabenko, Morze, Boiko et al., 2021) (Table 3):

- the creation of electronic content;

- the organization of webinars (video conferencing services);

- communication via messengers (messengers, groups in social networks);

- group work management (services to organize group work and interaction);

- the engagement and delivery of surveys (tools for online surveys, polls and quizzes);

- the organization of joint work on documents (shared documents (presentations) and cloud storages, virtual boards).

Ta ble 3. Digital tools for organizing distance learning

\begin{tabular}{|c|c|}
\hline Purpose of digital tools & Examples of digital tools \\
\hline \multicolumn{2}{|c|}{ Tools enabling design of electronic content } \\
\hline Long read & Atavist, Medium, Ready Mag, ShortHand \\
\hline Tools to design and edit images & Canva, GIMP, Awesome Screenshot \\
\hline Tools for visualization & $\begin{array}{l}\text { Visme, Easel.ly, Google Charts, Piktochart, } \\
\text { Venngage, Canva }\end{array}$ \\
\hline Tools to create presentations & Prezi, Moovly, Emaze, Beautiful.ai \\
\hline $\begin{array}{l}\text { Tools to create interactive } \\
\text { content }\end{array}$ & $\begin{array}{l}\text { LearningApps, Ceros , Mapme, Apester, Playbuzz, } \\
\text { Biteable, Playbuzz }\end{array}$ \\
\hline Screen capture tools & Snagit, Greenshot, Fireshot, Lightscreen \\
\hline Tools to create video & $\begin{array}{l}\text { Mozilla Popcorn Maker, Meograph, Windows Live } \\
\text { Movie Maker, Avidemux, DaVinci Resolve, iMovie }\end{array}$ \\
\hline Tools to create collages & Canva, Pro-photos, Mycollages \\
\hline Tools to create comic books & $\begin{array}{l}\text { Paint, Power Point, Tux Paint, Pixton, Storybird, } \\
\text { Animatron }\end{array}$ \\
\hline Tools to create animation films & Powtoon, Animaker \\
\hline Tools to create word clouds & Tagul, Tagxedo, Wordle i Word Clouds \\
\hline $\begin{array}{l}\text { Interactive books and interac- } \\
\text { tive sheets }\end{array}$ & Smilebox, Storyjumper, Live Worksheets \\
\hline \multicolumn{2}{|c|}{ Tools for a variety of purposes } \\
\hline Organization of webinars & $\begin{array}{l}\text { Zoom, Google Meet, Skype, Cisco Webex Meetings, } \\
\text { Microsoft Teams }\end{array}$ \\
\hline $\begin{array}{l}\text { Organization of communica- } \\
\text { tion via messengers }\end{array}$ & Viber, WhatsApp, Telegram, Slack \\
\hline Group Work management & Microsoft Teams, Granatum, Space Training \\
\hline $\begin{array}{l}\text { Engagement and delivery of } \\
\text { surveys }\end{array}$ & $\begin{array}{l}\text { Kahoot!, Socrative, Plickers, Quizizz, Quizalize, } \\
\text { Mentimeter, Classtime, Mentimeter, Poll Every- } \\
\text { where, Google Forms, EDpuzzle, ClassMaker }\end{array}$ \\
\hline
\end{tabular}




\begin{tabular}{ll}
\hline $\begin{array}{l}\text { Organization of joint work on } \\
\text { documents }\end{array}$ & Notion, G Suite \\
\hline Tools to create mind maps & $\begin{array}{l}\text { XMind, Mindmeister, Mindjet Coggle, WiseMap- } \\
\text { ping, Mind42, FreeMind, Spider Scribe, Mindomo }\end{array}$ \\
\hline Virtual digital boards & $\begin{array}{l}\text { WikiWall, Tutorsbox, Glogster, Dabbleboard, } \\
\text { Twiddla, Scribblar, Padlet, Educreations, Popplet, } \\
\text { Realtimeboard (Miro), Twiddla }\end{array}$ \\
\hline $\begin{array}{l}\text { Digital tools to organize ex- } \\
\text { ploratory learning }\end{array}$ & GoLab System Go-Lab \\
\hline
\end{tabular}

\section{Learning management system}

Moodle, Google Classroom, Go-Lab ecosystem

S ou r c e: Dziabenko, Morze, Boiko et al., 2021.

In the system of the purposeful building of teachers' capacities to develop social and emotional skills in children in the context of distance and mixed learning, it is important not only to focus on the development of teachers' information and digital competence and digital skills but also to provide examples of the comprehensive use of digital technologies for the development of soft skills. These examples include tools designed by Microsoft that proposes 5 steps for SEL integration in teaching and learning through various technologies used at each step (OECD, 2021):

1. Develop an emotional vocabulary with SEL chatbot, Reflect app, Teams whiteboard.

2. Help students build strategies and practice with Minecraft's Mindful Knight, Teams breakout rooms to develop listening, communication, cooperation and conflict resolution skills, the Flipgrid app for video discussions.

3. Observe and provide feedback using Education Insights, surveys.

4. Recognise milestones and build self-worth by sending praise badges with video or chat, coach app, icebreaker bot, using Teams video, emojis, OneNote video.

5. Enjoy using Teams and make it personal, make learning enjoyable for all with assistive technologies and learning tools.

In addition, scientists and educators involved in the implementation of SEL during the pandemic support members of their national communities, which are created specifically to discuss emerging issues in such areas as (Yoder, Posamentier, Godek, Seibel, \& Dusenbury, 2020):

- exchange of experience in introducing distance and blended learning through webinars;

- preparation of methodological and didactic materials for teachers on the use of digital tools for communication between students, students and teachers and posting them on special sites on the Internet;

- involvement of parents in the use of digital tools in teaching children in distance learning;

- the organization of individual assistance to students by the community and teachers; 
- conducting consultations to support students in learning during the implementation of distance learning from community professionals for teachers, parents and students.

\section{CONCLUSION}

To be successful in the $21^{\text {st }}$ century, it is essential that children acquire social and emotional skills, related to such concepts as 'soft skills', 'transversal skills', interpersonal skills', 'skills of the 21st century', all of which are instrumental for coping with life changes in today's highly globalized and dynamic world. Research findings show that social and emotional skills have a positive impact on academic performance.

Moreover, the role of soft skills becomes even more important in a crisis. OECD researchers highlight that lack of proper socialization with peers and teachers due to the forced restrictions during the COVID-19 pandemic and missed school time affect not only children's academic performance but also their mental state, adaptability, and interpersonal communication.

The survey conducted in Ukraine has demonstrated that both teachers and school principals recognize the importance of building social and emotional skills in the course of education and are prepared to implement SEL in their schools. However, they lack relevant in-service training, knowledge of methodologies, model curricula and the necessary methodological and learning materials.

The transition to distance-learning has highlighted the need to build strong social and emotional skills for students to remain focused and motivated in challenging learning environments and other situations of crisis. Therefore, current and future teachers should be provided with opportunities to master and use SEL tools, be aware of relevant methodologies and didactic materials suitable for different age groups, and also should show competence in using digital tools in the transition from more traditional forms of learning to distance or mixed learning.

All of the above aspects require targeted efforts to strengthen information and communication competence in teachers and school principals to facilitate the development of social and emotional skills in children using digital technologies.

\section{REFERENCES}

ABC Learning Design method by C. Young \& N. Pe rović, UCL (2015) is licensed under CC BY NC SA 4.0. Learning types, L a u rilla rd, D. (2012). Teaching as a Design Science. Download at abc-ld.org.

Cherny shen ko, O., Ka n ka ra š, M. \& D r a sgow, F. (2018). Social and emotional skills for student success and well-being: Conceptual framework for the OECD study on social and emotional skills. OECD Education Working Papers, No. 173, OECD Publishing, Paris. https://doi.org/10.1787/db1d8e59-en.

Collaborative for Academic, Social, and Emotional Learning (CASEL). (2013). CASEL | Success in school: Skills for life. Retrieved from www.casel.org (accessed April 1, 2013). 
Dziabenko, O., Morze, N., B oiko, M., Varchenko-Trotsenko, L., Vember, V., Vasylenko, S., Vorotnikova, I., \& Smyrnova-Trybulska, Y. (2021). Innovative pedagogical methods in the digital era. Manual. Kamianets-Podilsky. Ruta Publisher. 320 p. [in Ukraine]. ISBN 978-617-8021-05-4.

Eli a s, M.J., Zi n s, J.E., W e i s s b e r g, R.P., Fr e y, K.S., G r e e n b e r g, M.T., H a y n e s, N.M. et al. (1997). Promoting social and emotional learning: Guidelines for educators. Alexandria, VA: Association for Supervision and Curriculum Development. ISBN-0-87120288-3.

Gre sh a m, F.M. (2002). Teaching Social Skills to High-Risk Children and Youth: Preventive and Remedial Strategies. In M.R. Sh in n, H.M. Walker, \& G. S to n e r (Eds.). Interventions for academic and behavior problems II: Preventive and remedial approaches (pp. 403-432). National Association of School Psychologists.

Gresh m a n, F.M., \& Elli ot t, S.N. (1984). Assessment and classification of children's social skills: A review of methods and issues. School Psychology Review, 13, 292-301.

Handbook of social and emotional learning: research and practice / edited by J.A. D u r la k, C.E. D o m it rovi ch, R.P. We i s s b e r g, T.P. Gullot ta. ISBN 978-1-4625-2015-2 (hardback) ISBN 978-1-4625-2791-5 (paperback).

H r yn ev y ch, L., D ro z h z h y a, T., H lo b a, O. et al. (2021). Feasibility Study on Opportunities for SEL within New Ukrainian School Reform - Analytical Overview. Kyiv, Shkilny Svit Publishing Group, 312 p. (pp. 228-229). ISBN 978-617-7644-49-0.

Hrynevych, L., Ili ich, L., Lyniov, K., Morze, N., Protsenko, O., Proshkin, V., Riy, H., \& Shemelynets, I. (2020). Organization of Education Process in Ukrainian Schools under the Quarantine: Analytical Brief. Collective monograph. Kyiv: Borys Grinchenko Kyiv University, 76 p.

OECD (2021). Beyond Academic Learning: First Results from the Survey of Social and Emotional Skills, OECD Publishing, Paris. https://doi.org/10.1787/92a11084-en.

OECD (2021). Support students outside the classroom with social and emotional learning. Social Emotional Learning Activities \& Curriculum | Microsoft Education https://www. microsoft.com/en-us/education/educators/social-emotional-learning.

Sala, A., P un ie, Y., Garkov, V., \& Cabrera Girald e z, M., (2020). LifeComp: The European Framework for Personal, Social and Learning to Learn Key Competence, EUR 30246 EN, Publications Office of the European Union, Luxembourg. ISBN 978-92-7619417-0, https://doi.org/10.2760/922681, JRC120911.

Yoder, N., Pos a mentier, J., Godek, D., Seibel, K., \& D u s enbury, L. (2020). From Response to Reopening: State Efforts to Elevate Social and Emotional Learning during the Pandemic. Collaborative for Academic, Social, and Emotional Learning (CASEL); Committee for Children https://eric.ed.gov/?id=ED610659. 